\title{
Soil salinization in the Nile Delta and related policy issues in Egypt
}

\author{
Tarek H.S. Kotb ${ }^{\mathrm{a}, *, 1}$, Tsugihiro Watanabe ${ }^{\mathrm{b}}$, Yoshihiko Ogino ${ }^{\mathrm{b}}$, \\ Kenneth K. Tanji ${ }^{\mathrm{c}}$ \\ a Ministry of Public Works and Water Resources of the Arab Republic of Egypt, Giza, Egypt \\ ${ }^{\mathrm{b}}$ Faculty of Agriculture, Osaka Prefecture University, 1-1 Gakuencho Sakai, Osaka 599-8531, Japan \\ ${ }^{\mathrm{c}}$ Department of Land, Air and Water Resources-Hydrology Program, University of California, Davis, \\ CA 95616-8628, USA
}

Accepted 29 March 1999

\begin{abstract}
The soil salinization problem in Egypt's Nile Delta and related policy issues are addressed in regards to the need to create water supplies for new irrigation projects by, for instance, re-use of irrigation drainage waters and limits on rice plantings, and at the same time improving the agricultural productivity of the Nile Delta through, for instance, subsurface drainage in waterlogged lands, land leveling and use of gypsum amendments. A brief background on the climate, agriculture and crop rotation patterns, and water and land resources and their salinities is provided. The paper describes countermeasures taken by the government on a national and regional scale and farmers on a local or field scale. The farmer's participatory role in adapting to changes in cropping, water and soil salinity, and national needs are crucial. Emphasis is laid on the advantages and benefits of rice cultivation in drainage- and salt-impacted lands of the northern Delta. But use of rice paddies to control salinity is faced with a number of constraints such as periodic shortfalls in supply of irrigation water, salinity of supply waters consisting of a blend of fresh and drainage waters and diversified cropping, including rice, in a given subsurface drainage system. We strongly support the recommendations for rice cultivation only in saline soils of the Delta but perceive that enforcement of such a policy may be difficult to achieve and long-term changes in salinity of delta waters are not clearly known with increased drainwater re-use. (C) 2000 Elsevier Science B.V. All rights reserved.
\end{abstract}

\footnotetext{
* Corresponding author. Tel.: +81-0722-54-9437; fax: +81-0722-54-9918. E-mail address: tarek@envi.osakafu-u.ac.jp (T.H.S. Kotb).

${ }^{1}$ Present address: Faculty of Agriculture, Osaka Prefecture University, 1-1 Gakuencho Sakai, Osaka 5998531, Japan.
} 
Keywords: Salinity countermeasures; Cropping pattern; Paddy rice; Drainwater re-use; Subsurface drainage; Farmer's participatory role

Abbreviations: AEI, Agriculture Economic Institute; DRI, Drainage Research Institute; EALIP, Executive Authority for Land Improvement Projects; EPADP, Egyptian Public Authority for Drainage Projects; GARE, Government of the Arab Republic of Egypt; MALR, Ministry of Agriculture and Land Reclamation; MPWRDU, Master Plan for Water Resources Development and Use; MPWWR, Ministry of Public Works and Water Resources; RIGW, Research Institute for Ground Water; WMISRI, Water Management and Irrigation Systems Research Institute

\section{Introduction}

Croplands in Egypt are 100\% irrigated since precipitation is very scarce and evaporation is very high. The intensive irrigation of cropland under an arid climate is the main reason for secondary soil salinization in Egypt. Practically all of its irrigation water is obtained from the River Nile that originates outside Egypt's borders. Its share from the River Nile is extensively recycled in agriculture to fulfil the increasing water demands of different sectors of the society. Development of potentially productive new irrigated lands has become a necessity to meet the nation's current and future needs for food and fiber.

Recently, the government has started to fund two gigantic projects that aim at reclaiming 210000 ha in the southwestern part of the country (New Valley Canal Project) and 250000 ha in the eastern Nile Delta and northwestern Sinai (El-Salam Canal Project) (Fig. 1). The new expansionist attitude adopts a leap-frog pattern, instead of the old one, creeping pattern. The latter resulted in confining the agricultural lands to the fringes of the Nile Valley and Delta while the former develops new irrigated lands by leap-frogging.

This paper presents the agrarian environment in Egypt, focusing particularly on soil salinization and related policy issues. The efforts to control the salinity problem and the related policy issues are presented at both government (national) and private (farmers' contribution) levels. Within the same context, the effectiveness of rice cultivation as a countermeasure against soil salinity is discussed. Suggestions for proper co-ordination between concerned parties are proposed.

\section{Climate}

Egypt is located in the northeastern part of Africa between latitudes $22^{\circ}$ and $32^{\circ} \mathrm{N}$ and longitudes $25^{\circ}$ and $34^{\circ} \mathrm{E}$ (Fig. 1). Table 1 presents the prevailing climatic conditions at three locations. The climate is categorized as arid in the north (Alexandria) to extremely arid in the south (Aswan). The mean effective rainfall over the entire country is near zero since precipitation is nil. Daily evaporation ranges from 1.5 to $8.5 \mathrm{~mm}$ with a mean daily reference evapotranspiration from ca. 2.0 to $10.0 \mathrm{~mm}$ (MPWRDU, 1981). Thus, crop production requires intensive irrigation. 


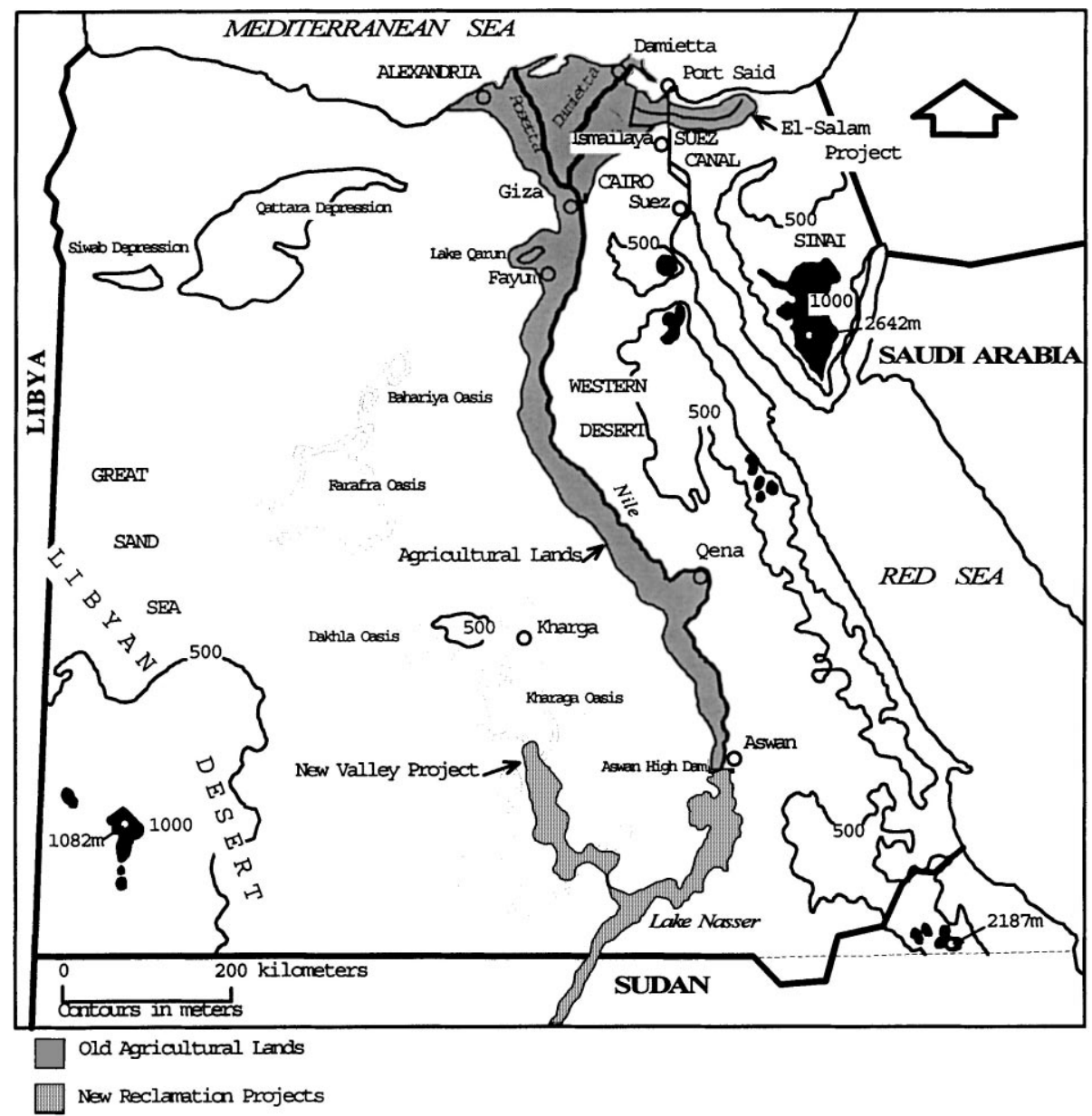

Fig. 1. Map of Egypt.

\section{Agriculture}

\subsection{Land use}

The total land area of Egypt is $\approx 100$ million ha (Mha). Egypt is considered as a heavily populated country, having 60 million people living on $<4 \%$ of the land, almost exclusively in the Nile Valley, Nile Delta and the sparse cities along the northern coastal periphery. The total cultivated area is $3.36 \mathrm{Mha}$. The per capita share of agricultural land is ca. 0.05 ha. Indeed, this figure is very low compared to the USA (5.88 ha) and Europe (1.26-1.68 ha) (MPWWR, 1997)

The agricultural lands are mainly occupied with widely diversified crops throughout the year. The average cropping area during the last five years accounts for 5.95 Mha, 
Table 1

Mean monthly climatological data in Egypt

\begin{tabular}{|c|c|c|c|c|c|c|c|c|}
\hline \multirow[t]{3}{*}{ City } & \multicolumn{4}{|l|}{ Temperature } & \multirow{3}{*}{$\begin{array}{l}\text { Rainfall } \\
\left(\text { mm year }^{-1}\right)\end{array}$} & \multirow{3}{*}{$\begin{array}{l}\text { Relative } \\
\text { humidity (\%) }\end{array}$} & \multirow{3}{*}{$\begin{array}{l}\text { Relative duration } \\
\text { of bright } \\
\text { sunshine }(\%)\end{array}$} & \multirow{3}{*}{$\begin{array}{l}\text { Evaporation } \\
\left(\mathrm{mm} \mathrm{day}^{-1}\right)\end{array}$} \\
\hline & \multicolumn{2}{|l|}{ January } & \multicolumn{2}{|l|}{ August } & & & & \\
\hline & maximum $\left({ }^{\circ} \mathrm{C}\right)$ & minimum $\left({ }^{\circ} \mathrm{C}\right)$ & $\operatorname{maximum}\left({ }^{\circ} \mathrm{C}\right)$ & minimum ${ }^{\circ} \mathrm{C}$ ) & & & & \\
\hline Alexandria & 18.5 & 9.3 & 30.6 & 22.8 & 191.8 & $65-72$ & $63-89$ & $1.6-7.5$ \\
\hline Giza & 19.5 & 6.4 & 34.4 & 20.4 & 20.2 & $53-73$ & $68-86$ & $1.5-7.7$ \\
\hline Aswan & 24.2 & 9.5 & 42 & 26.4 & 1.4 & $18-41$ & & $2.8-8.5$ \\
\hline
\end{tabular}

Source: Aboukhaled et al. (1975). 
resulting in an average cropping intensity of 1.8 or nearly two crops per year. Actually, the majority of agricultural land is cultivated twice a year, with the remaining land being left fallow during one season because the soil is saline or water-logged, or because of insufficient irrigation water. The Egyptian farmer may simultaneously cultivate two crops at the same site; for instance, onion may be inter-planted with cotton and the water duty for cotton is merely supplied. The agricultural soil in the Nile Valley and Delta is of fine texture (medium-to-heavy clay). The clay content increases in the Nile Delta toward the Mediterranean Sea.

\subsection{Crop rotation patterns}

The major cropping seasons are the winter (November-May) and the summer (MayOctober) seasons. Another marginal season is the Nili season, that is named after the annual Nile flooding of the past, or late summer season (August-October). The main winter crops are wheat, barley, Egyptian clover (Berseem), broad beans and vegetables, and the main summer crops are cotton, rice and maize.

Fig. 2 shows the two patterns of crop rotation practiced with, and without, rice. Both these types involve intensive farming. These crop rotation practices have been found beneficial to the agricultural soils with respect to nutrition and essential element recovery. When both these rotation patterns are firmly applied for three successive years, fertilizer demands would be reduced. The first rotation is practiced in rice areas, namely the Nile Delta, while the other is practiced countrywide. The rotation with paddy culture helps to leach soils and consequently, controls soil salinity to a considerable extent, as will be discussed later. The crop rotations are still practiced despite the recent economic and institutional reforms, which are targeted to crop liberalization and gradual retrenchment of subsidies. The Ministry of Agriculture and Land Reclamation (MALR) is, however, still monitoring the cropping patterns. The intended liberalization policy has not been fully implemented since the agricultural inputs are still subsidized and irrigation services are free of charges. Table 2 may help realize the effect of such subsidy in view of some available data. The table includes a comparison between the production costs of 1 ha of rice and cotton in Egypt and California, USA, during 1993. The land-renting fee, which is common in the Egyptian farming society, was not considered for the sake of a fair comparison. The table shows that the production cost in California was higher than in Egypt by $37 \%$ for rice and $33 \%$ for cotton. Moreover, the subsidy in Egypt could be more

Table 2

Comparison between the production cost in US\$ per ha for rice and cotton in Egypt and California (USA) in 1993

\begin{tabular}{|c|c|c|c|c|}
\hline \multirow[t]{2}{*}{ Crop } & \multicolumn{2}{|c|}{ Production cost } & \multirow[t]{2}{*}{ Difference } & \multirow[t]{2}{*}{ Difference $(\%)$} \\
\hline & Egypt & California & & \\
\hline Rice & 689 & 1088 & 399 & $37 \%$ \\
\hline Cotton & 605 & 904 & 299 & $33 \%$ \\
\hline
\end{tabular}

Sources: MALR (1994); U.S. Bureau of Reclamation (1997). 


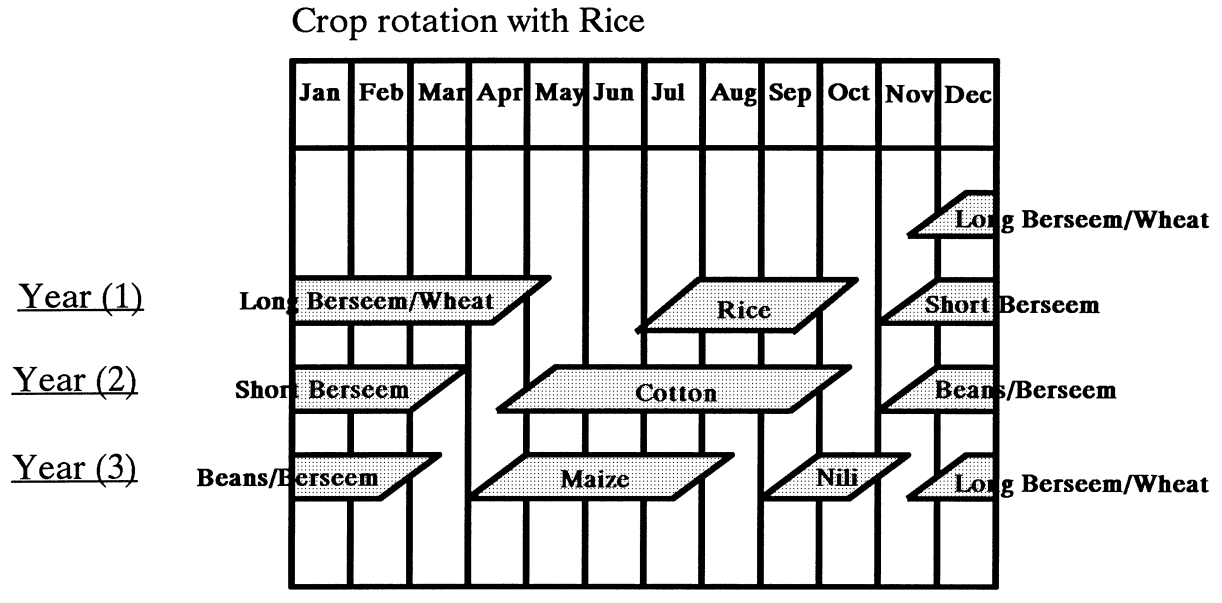

Crop rotation without Rice

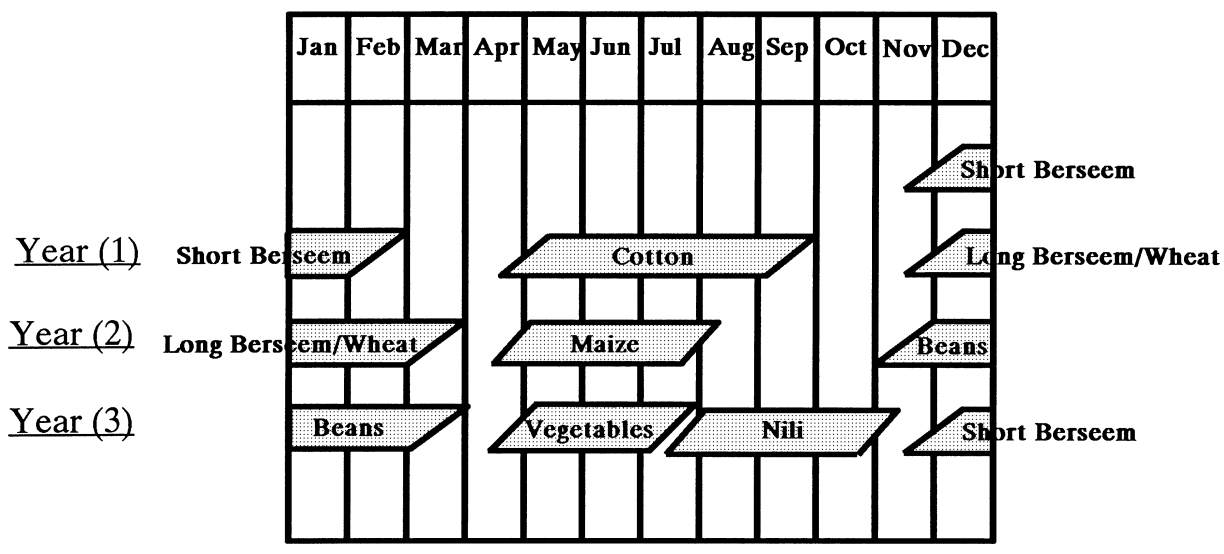

Fig. 2. Crop rotation patterns in Egypt.

than that indicated, because in California farmers pay for the delivery of water to their farm gate while farmers in Egypt do not pay for the water.

Table 3 summarizes the net benefit for the main summer crops in Egypt during 1994. A comparison of the net returns shows that growing rice is of the maximum benefit to farmers.

The Government officially controls the areas cultivated with rice and cotton. Paddy rice is known as a heavy water-using crop due to runoff and seepage losses in addition to evapotranspiration, and its cultivation is prohibited in Upper and Middle Egypt where evaporation rate is very high and flooding would waste considerable quantities of the 
Table 3

Comparison among the net benefit from main summer crops in Egypt in Egyptian pound per hectare $\left(\operatorname{LE~ha~}^{-1}\right)$

\begin{tabular}{llll}
\hline Crop & Cost & Return & Net benefit \\
\hline Rice & 2794 & 4952 & 2158 \\
Cotton & 3334 & 4790 & 1455 \\
Maize & 2394 & 3387 & 993 \\
\hline
\end{tabular}

Note: One LE is equivalent to US\$ 0.3 .

Source: MALR (1994).

scarce water resources. Paddy cultivation is only limited to the Nile Delta, particularly intensified at the northern part, where salinity problem is at its severest. Officially, growing rice requires obtaining a cultivation permit from the Ministry of Public Works and Water Resources (MPWWR). Violating the MPWWR's policy in this respect is financially penalized. However, the Government is usually lenient toward violators, seeking political stability in the rural societies.

Cotton is another strategic crop, which is subsidized by the government. In reality, farmers are not favoring cotton cultivation for the reason that it is always threatened by blight infestations. Further, market manipulation by the Government may discourage farmers from growing cotton because the prices are sometimes fixed at unsatisfactory rates.

\section{Water}

\subsection{Water resources}

Egypt is completely dependent on water from the River Nile, obtaining $95 \%$ of its total water supply from this source. Its annual share is $55.5 \times 10^{9} \mathrm{~m}^{3}$, according to the articles of the agreement regarding the full utilization of the Nile water established between Egypt and Sudan in 1959. Agriculture utilizes ca. $90 \%$ of the available water. About $12.3 \times 10^{9} \mathrm{~m}^{3}$ of drainage water, mainly produced by irrigated agriculture, and including the freshwater released during the winter closing, is disposed annually into the Mediterranean Sea (DRI, 1994), while an amount of about $4.6 \times 10^{9} \mathrm{~m}^{3}$ is officially recycled, particularly in the Nile Delta [see Fig. 3 for the water balance in Egypt and interrelations among sources and utilities (Kotb et al., 1998)]. In order to prevent seawater intrusion into the northern strip of the Nile Delta, ca. $10 \times 10^{9} \mathrm{~m}^{3}$ must be disposed yearly into the Mediterranean Sea. The country's policy is to increase the drainage re-use to ca. $7 \times 10^{9} \mathrm{~m}^{3}$ (ca. $2.4 \times 10^{9} \mathrm{~m}^{3}$ increase) by the year 2000 , which will bring the flow to sea down to about the permissible lower threshold. The recycled drainage flow is targeted to irrigate newly developed lands at the fringes of the Nile Valley and Delta after being blended with freshwater in specific ratios subject to its quality, as will be shown later. The groundwater reservoir in the Nile Valley and Delta is comparatively insignificant, but serves as a basin to recycle deep percolation irrigation water. About 


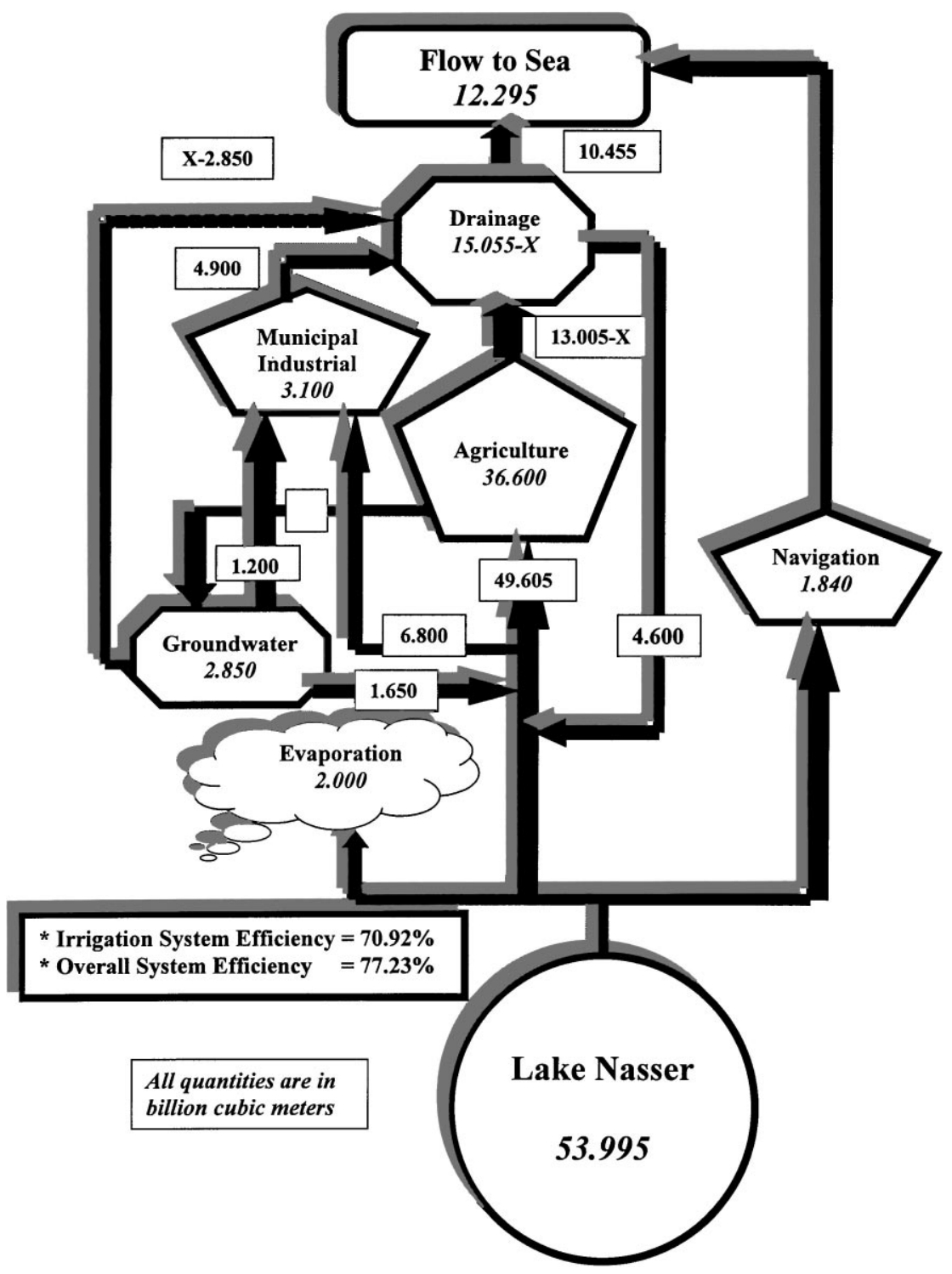

Fig. 3. National water balance of Egypt (1989/1990).

$2.6 \times 10^{9} \mathrm{~m}^{3}$ is annually pumped by means of shallow wells. The non-renewable aquifers in the extensive deserts and the Sinai Peninsula, which are not interrelated to the Nile Valley and Delta, have not been significantly utilized yet despite their high potentials. Pumping these waters may become economically feasible in the near future. Groundwater exploitation is hoped to achieve a safe pumping yield of $5 \times 10^{9} \mathrm{~m}^{3}$. 


\subsection{Water quality}

Although all the agricultural drains in Upper and Middle Egypt discharge their flow (ca. $2.3 \times 10^{9} \mathrm{~m}^{3}$ ) into the River Nile, the river-salinity level has not been significantly affected. The concentration of the total dissolved solids (TDS) is ca. $150 \mathrm{mg} \mathrm{l}^{-1}$ at Aswan, the upstream point of the system, and ca. $250 \mathrm{mg} \mathrm{l}^{-1}$ near Cairo, $950 \mathrm{~km}$ downstream. This small increase of TDS relative to the long distance is ascribed to the high dilution effect of the River Nile. However, the situation at the northern part of the Nile Delta is not that positive. The two river branches, Damietta and Rosetta, are vastly contaminated by industrial effluents close to their outlets into the Mediterranean Sea.

Water is conveyed from the river to irrigated lands through a complicated network of canals of different orders. Currently, there is no comprehensive monitoring of the salinity level in canal waters, however, there are some representative figures measured by the Water Management and Irrigation Systems Research Institute (WMISRI) at the off-takes of some selected canals. For example, at El-Mansouraya canal in Middle Egypt, the maximum salinity during December was $570 \mathrm{mg}^{-1}$, and at Bahr Mouice canal off-take, at the East of the Nile Delta, the recorded salinity was $310 \mathrm{mg}^{-1}$ during May (WMISRI, 1995). Also, the data helps conclude that the bicarbonate ions in the sample canal water, even after mixing with some drain waters, lies in the range from 2 to 3 meq $1^{-1}$, which is acceptable according to Ayers and Westcot (1976); Ayers and Westcot (1985). Drainage water generally has similar characteristic with respect to bicarbonate ions (DRI, 1994). However, in the mass balance of salts, the potential precipitation of calcite and gypsum in the soil, dependent upon leaching fraction of applied water, should be taken into account.

The local complaints and crops reflect adverse water quality situation at lower order canals. The reason is the pollution mainly caused by both, domestic and industrial effluents.

The salinity of groundwater withdrawn in the Valley and Delta is reported to be within water-quality limits. An inventory conducted by the Research Institute for Groundwater (RIGW) concluded that the salinity of the groundwater aquifers is mainly below $1500 \mathrm{mg} \mathrm{l}^{-1}$ over the entire country; however, it was measured at $5000 \mathrm{mg} \mathrm{l}^{-1}$ in some regions near the Mediterranean coast (RIGW, 1992). The average reported salinity of pumped groundwater lies in the range from 160 to $480 \mathrm{mg} \mathrm{l}^{-1}$ in the South Delta, 480 to $1440 \mathrm{mg} \mathrm{l}^{-1}$ in the Middle Delta and $>3200 \mathrm{mg} \mathrm{l}^{-1}$ in the coastal plain. Seawater intrusion, deep percolation of high salinity irrigation water and seepage from drains containing saline waters cause the latter high salinity. Some irrigation engineers believe, although without concrete proof, that farmers divert saline drainage water for irrigation in large quantities when water-shortage conditions prevail in the Delta. The amount of recycled drainage water is large relative to the total input water to the agricultural system. Typically, saline drainage water is mixed with fresh canal water at designated points across the upper order canals and drains. Lately, some mixing stations have completely been shut down due to severe contamination by municipal and industrial pollutants. Some mixing stations have recorded a salinity level of $3000 \mathrm{mg} \mathrm{l}^{-1}$, as in the case of Mariout Mixing Station in the western Nile Delta; however, it is still in operation. At a microlevel, farmers intensively pump drain water whenever a shortage occurs in tertiary canal water. 


\section{Soil salinization}

\subsection{Overview}

An early soil survey indicated that the percentages of salt-affected soils relative to total cultivated lands was $60 \%$ in the Lower Delta, $25 \%$ in the Middle Delta, 20\% in the Upper Delta and Middle Egypt, and 25\% in the Upper Egypt (Aboukhaled et al., 1975). A rather recent inventory concluded that almost $35 \%$ of the agricultural lands (ca. $1 \mathrm{Mha}$ ) in Egypt suffer from salinity, wherein the electrical conductivity of the extract from saturated soil is higher than $4 \mathrm{dS} / \mathrm{m}$ (GARE, 1992). The majority of the salt affected lands exist in the Lower Delta. Indeed, the current situation is serious and threatens not only the agricultural sustainability, but also the whole ecological system.

\subsection{The Nile Valley}

In the Nile Valley, water is always in ample quantities and shortages only take place at the remote downstream ends of conveyances. When the traditional flood basin irrigation was substituted by perennial method without establishing an adequate drainage system, farmers started to experience soil salinization problems. Firstly, the soil became waterlogged as the water table rose quickly from excess irrigation, while the prevailing high temperatures during summer were causing rapid evaporation at the soil surface, leaving salts to accumulate in the topsoil. The recent standards regarding the Egyptian conditions define water-logged land as: "The area, which has a groundwater table at a depth less than $80 \mathrm{~cm}$ below surface for a period more than two months during the winter season" (Attia and Leeuwen, 1994).

Furthermore, the situation was highly aggravated by improper land leveling, effect of less impermeable plow sole, seepage of drainage water from higher newly reclaimed areas at the fringes of the valley to down-slope sites and frequent re-use of drainage flow.

In general, the causes of soil salinization in the Nile Valley include a high water table, resulting from either over-irrigation or insufficient drainage system, irrigation with salty drainage and groundwaters, accumulation of surface runoffs in low-lying areas, lateral movement of subsurface water from up slope to down-slope irrigated lands, and overuse of salt-generating agrochemicals.

\subsection{The Nile Delta}

Salt-affected soils, in spite of their scattered occurrence, mainly exist in the northern part of the Nile Delta. In the Mediterranean coastal plains and lower Delta, excessive rates of groundwater withdrawal has resulted in a large drop in the water table and, as a consequence, seawater intruded into the aquifers (GARE, 1992). The main reasons for soil salinity in these areas include seawater intrusion, irrigation with low quality (saline) water as they are located at the downstream regions of the system, and an inadequate field drainage. Fig. 4 gives a classification of salt-affected soils in the Nile Delta.

Basically, soil salinity problems related to irrigation with low quality (saline) water occur when salts accumulate in the crop-root zone and, consequently, the available water 


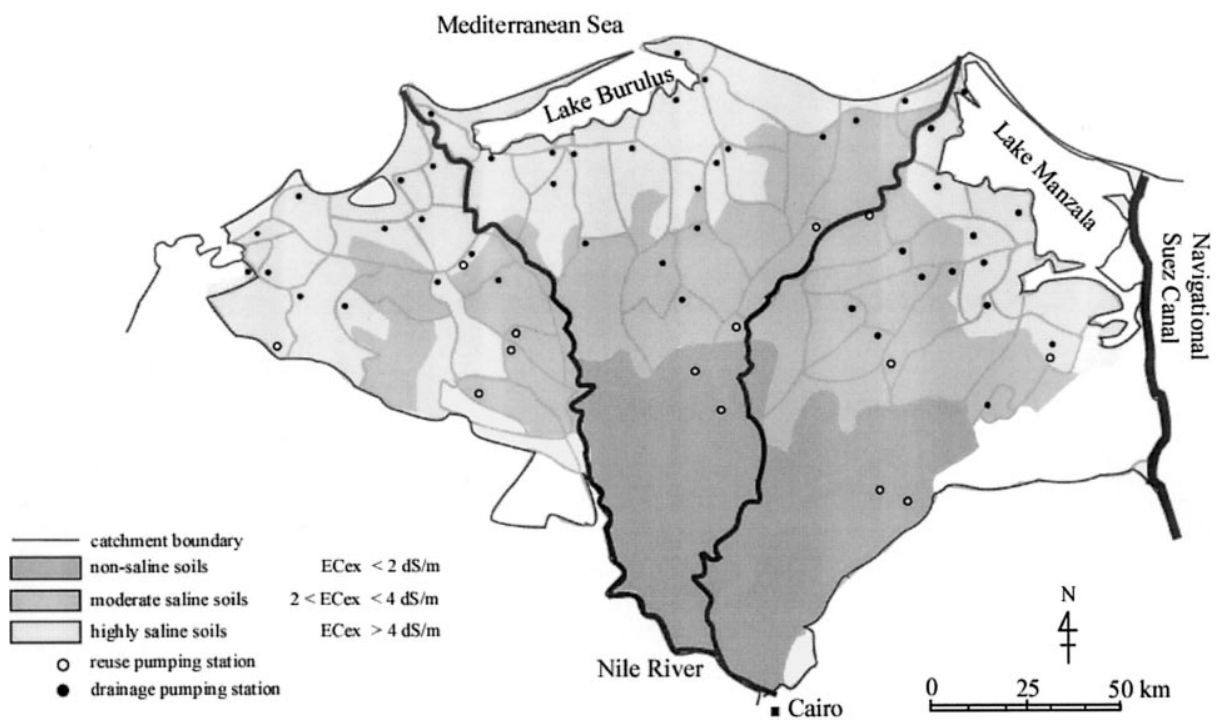

Fig. 4. Categorization of the salt-affected soils in the Nile Delta (El-Gunidy, 1989).

in soil for the crop is reduced. Another possibility, where a shallow groundwater table exists and as a result of upward movement of water-containing salts, evapotranspiration leads to a salt accumulation in the top soil. This type of secondary soil salinization is mainly attributed to poor drainage conditions. Once, proper drainage is installed and the groundwater table is stabilized at deeper depths, either the salinity problem would be controlled, or recognized as a problem of the first type, i.e. the applied irrigation water is too saline.

Fig. 5 indicates the range of drainage rates in the Nile Delta. The general conclusion is that, apart from a few and small catchments in the Middle and South Delta, the majority of the areas with high drainage rates $\left(5.22-10.68 \mathrm{~mm} \mathrm{day}^{-1}\right)$ lies along the coastal plain. These areas are considered the last sites for water recycling before the final disposal into the Mediterranean Sea and Terminal Lakes. The average drainage rate in Egypt is assumed to be $1 \mathrm{~mm} \mathrm{day}^{-1}$ for the design of subsurface drainage system according to the above-mentioned conditions (Abdel-Aziz, 1997). Normally, the assumed drainage rate is adequate for properly operating systems as in the case of the South Delta. In contrast, the high drainage rates in the North Delta cause an inadequate drainage system and result in high water tables. Moreover, the North Delta catchments may become water-logged by the intruding sea water. Fig. 6 may support this contention, since the majority of the Lower Delta catchments are draining highly salinized water of $>2500 \mathrm{mg} \mathrm{l}^{-1}$.

\subsection{Oases}

In the scattered oases of the Western Desert, some limited agricultural activities are practiced using groundwater. These isolated areas suffer from lack of natural outlets for disposing drainage effluents intertwined with the overuse of irrigation water and 


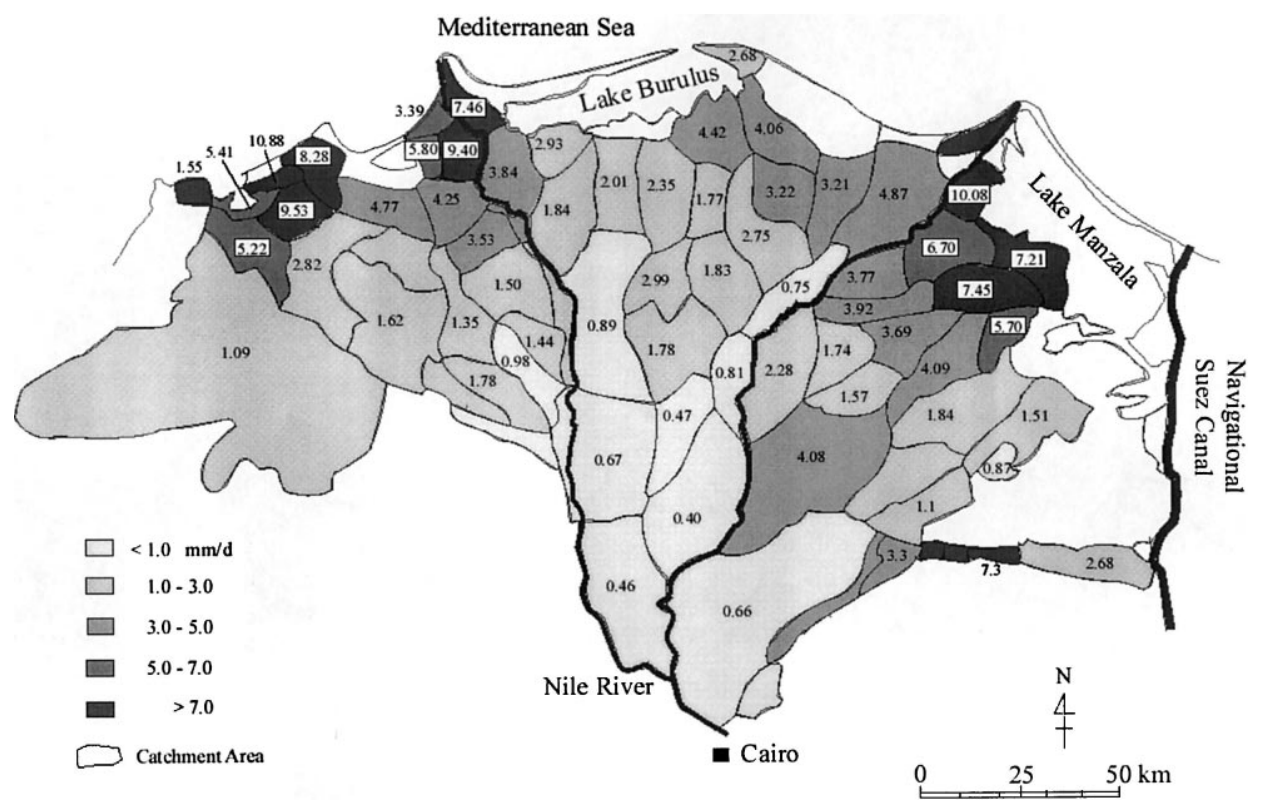

Fig. 5. Drainage rates in the Nile Delta in $\mathrm{mm} \mathrm{day}^{-1}$ during 1992/1993 (DRI, 1994).

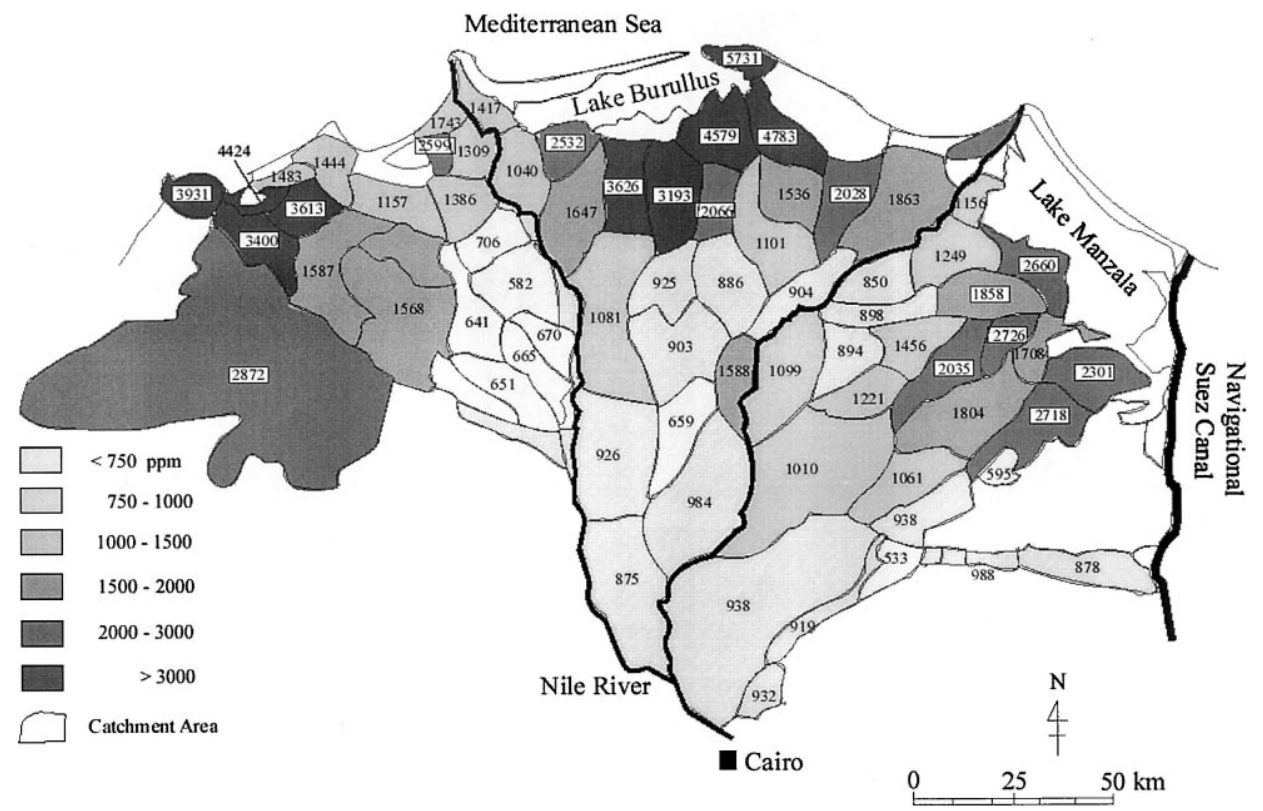

Fig. 6. Average salinity of drainage water in the Nile Delta in $\mathrm{mg} 1^{-1}$ during 1992/1993 (DRI, 1994). 
inadequate drainage system. A shallow water table has developed over time, causing water-logging. As a result of evaporation of shallow water tables, the soils have been progressively salinized.

\section{Countermeasures to control soil salinization}

\subsection{Government efforts in subsurface drainage}

The severity of the salinization problem has forced both government and private sectors to work jointly to alleviate production losses from drainage-impacted lands. The Egyptian Public Authority for Drainage Projects (EPADP) of the MPWWR has installed a network of subsurface drainage in ca. $50 \%$ of the total cultivated areas in Egypt. As indicated in Table 4, crop yields have markedly increased after completion of the first phase of tile drainage projects in 250000 ha of the Nile Valley and Delta.

In 1984, the Agricultural Economic Institute (AEI) of the MALR, in collaboration with the EPADP, conducted a study aimed at investigating the farmers' ability to pay for the annual instalments of the ongoing cost recovery program of tile drainage. This study revealed that the net income was higher in tile-drained farms as compared to those not drained, 11-14\% in the Nile Delta, 9-16\% in Upper Egypt and 28-44\% in Qena and Aswan governorates where high levels of salinity had been measured [see Fig. 1 for the location of the two governorates]. Such significantly improved net returns due to subsurface drainage projects have encouraged farmers to participate fully in the cost recovery program. The Government's plan is aimed at installing subsurface drainage system countrywide where drainage is needed by the year 2010 .

The Government has, moreover, initiated an ambitious land improvement program. The executive authority is vested with carrying out sub-soiling or chiseling, land leveling by laser beam, mechanical cleaning of water courses, and application of gypsum amendment to control alkalization. The sub-soiling or chiseling is meant to improve the sub-soil drainage conditions by breaking up, destroying or at least rendering more permeable layers for roots and water (Ayers and Westcot, 1976; Ayers and Westcot, 1985). A substantial positive response in crop production is expected from this program, in particular, from using gypsum as a soil amendment and sub-soiling activities. A study conducted by the Executive Authority for Land Improvement Projects (EALIP) concluded that the effect of soil improvement on increasing crop production could

Table 4

Percentage yield increase after installing subsurface drainage systems in the Nile Valley and Delta

\begin{tabular}{ll}
\hline Crop & Yield increase (in \%) \\
\hline Wheat & 13 \\
Rice & 14 \\
Cotton & 15 \\
Maize & 16 \\
\hline
\end{tabular}

Source: GARE (1992). 
Table 5

Percent increase in crop production after soil improvement

\begin{tabular}{llllr}
\hline Crop & 1st Year & 2nd Year & 3rd Year & 4th Year \\
\hline Wheat & 26.9 & 23.9 & 13.5 & 4.8 \\
Broad beans & 39.0 & 36.8 & 25.8 & 7.9 \\
Rice & 47.0 & 46.1 & 37.8 & 10.7 \\
Cotton & 27.7 & 25.5 & 18.2 & 7.6 \\
Maize & 20.8 & 38.1 & 20.8 & 4.0 \\
Sugar cane & 25.1 & 29.6 & 25.6 & 20.8 \\
Summer potatoes & 34.2 & 40.5 & 18.6 & 6.5 \\
\hline
\end{tabular}

Source: GARE (1992).

attain the percentages indicated in Table 5. However, the table shows that the increase in yield has sharply dropped after three years, reverting to conditions prior to the initiation of the project. Therefore, it may be necessary to renew the soil improvement program every three years. The program has the capacity to carry out such periodic activities throughout the country.

\subsection{Salt balance and role of rice cultivation}

In regard to the salt balance principal, salts must be removed from the crop root zone by soil leaching in amounts more or less equal to those applied. In humid areas, rainfall may be adequate to leach accumulated soil salts. But in arid regions, like Egypt, additional water must be applied, either as pre-irrigation to leach out the accumulated salts from previous cropping or as leaching requirement of the crop (Ayers and Westcot, 1976; Ayers and Westcot, 1985) during the irrigation season. An inefficient field application of irrigation water (leaching fraction) may compensate for crop-leaching requirement. Although this leaching requirement practice is thought to prevail on a significant scale, it may be restricted by shortages in irrigation water supplies and inadequate drainage system. Applying adequate water of reasonable quality as leaching fraction along with installing adequate drainage network is the only sustainable solution to salt control in the root zone. However, this is complicated with the need for re-use of poor quality drainage waters when freshwater is short as well as the disposition of poor quality drain waters with minimal adverse impacts to agriculture and the environment.

The experiences inherited from the historical practice of irrigated agriculture in Egypt has promoted rice cultivation as the best solution for controlling soil salinization, reclaiming sodic soils and utilizing poor quality waters. In this respect, it is worth recalling an expressive managerial concept that was addressed by Ayers and Westcot (1976): "Poor water is often better than no water, and, if a water is useable, agriculture may need to find a use for it rather than discharge it as waste".

This concept is practiced in the intensive cultivation of rice in the northern part of the Nile Delta. In this region, not only the water quality is poor, but the soil is salinized to a considerable extent, as explained previously. However, since the Government is trying to keep a balanced cropping pattern with respect to available water resources, other crops are rotated with rice according to the adopted crop rotations. In this regard, rice 
cultivation is considered to be suitable for reclaiming salinized soils, besides being an important staple food. But in many cases, having to grow rice side by side with other crops in the same field results in a serious drainage problem and poor water management at a field level. Typically, when water is short and the soil is salinized, rice is cultivated during the land reclamation stage without rotation with other crops. Once the accumulation of soil salts is stabilized, other crops would replace rice. On the other hand, where water use is not restricted, rice is grown in large consolidated areas (monoculture cropping system). The situation in Egypt is unique and poses a problem to planners and designers of tile-drainage works (Van de Goor, 1967).

The area cultivated with rice fluctuates around 420000 to 630000 ha (El-Quosy, 1994). The MPWWR allocates an average yearly water duty of $21000 \mathrm{~m}^{3} \mathrm{ha}^{-1}$ in the rice-growing areas. The average rice yield on a national level is $8 \mathrm{tha}^{-1}$, which is one of the highest in the world. The vast amount of rice production is consumed locally, while $\approx 200000-300000 \mathrm{t}$ are exported every year. Fig. 7 shows that the intensity of rice cultivation is ca. $50 \%$ in the northern part of the Nile Delta during the summer season and decreases to $40 \%, 30 \%, 20 \%$ and $10 \%$ southward. Nurseries are planted late in May and the young plants are transplanted a month later in June. Harvesting usually takes place in October. The net return of rice production is higher than other summer crops, namely cotton, and the hazards of producing rice caused by pests are very low.

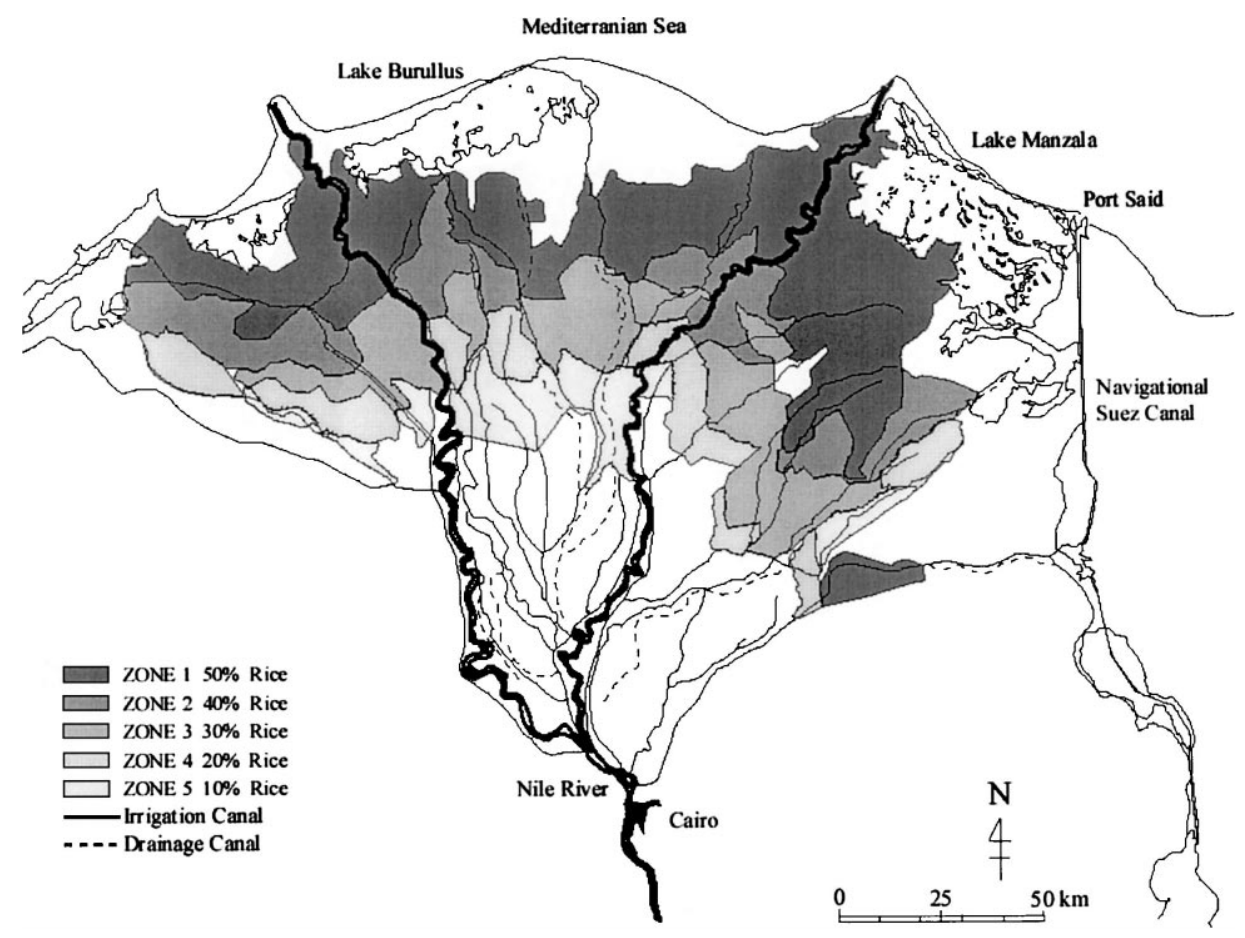

Fig. 7. Intensity of rice cultivation in the Nile Delta (El-Quosy, 1994). 


\subsection{Farmer's efforts in taking countermeasures to salinity}

El-Gunidy and Risseeuw (1987) recommend rice cultivation in salinized soils. They conducted research in an experimental farm (A. Hammad Farm), located in the western Nile Delta. On this farm, rice occupies $65 \%$ of the command and cotton $45 \%$ during the summer. In winter, clover occupies $45 \%$ and barley $15 \%$ of the farm, while $40 \%$ of the land is left fallow because of soil salinization. In order to assess the impact of growing rice and related farming practice on soil salinity, EC of extract from saturation soil was measured before, and after, the rice season, i.e. in June and November. Table 6 shows the average desalinization effect induced by rice cultivation during 1977 and 1978, while in 1979, although rice was also grown, a noticeable resalinization occurred.

Basically, if the water is supplied in sufficient quantities, paddy cultivation promotes desalinization brought about by winter crops or saline irrigation water. In the Nile Delta, where water is normally insufficient during the months of peak water use (June and July), desalinization by growing rice may not be significant. Moreover, the situation could be reversed and soil salinization level may increase as was reported during 1979 and is explained below.

Fig. 8(a and b) show the EC of different soil layers corresponding to the cropping pattern specified for three successive years in two designated plots (B and C) (El-Gunidy and Risseeuw, 1987). In Plot B, the desalinization effect can be observed after ricegrowing seasons in 1977 and 1978 (Fig. 8(a)) for all soil layers, except for the bottom layer in 1978 that could be subject to inaccurate measurement or accumulation of salts leached out from the upper layers, or insufficient drainage capacity. In Plot C, however, only a modest desalinization after rice cropping is shown for 1977, except for the lower layer that probably had conditions similar to those explained for the bottom layer of plot B during 1978, while a resalinization took place after rice sowing in 1979 (Fig. 8(b)). In the latter case, El-Gunidy and Risseeuw report that the soil profile could no longer be completely saturated because there was insufficient irrigation water at the beginning of the rice-growing season. The typical downward flux in paddy rice reversed itself and an upward flux of saline groundwater occurred instead. The soil profile was, therefore, subjected to re-salinization during this period that is illustrated considerably in the two lower layers (50-75 cm and 75-100 cm). Later, during the growing season, even though a sufficient supply of irrigation water was available, the accumulated salts could not be leached because of the peak water requirement of rice. Consequently, the soil salinity increased in the two lower depths by the end of the season.

A different perspective is obtained when the mass of salt input and output was balanced. The salt balance principal was applied to this farm before, and after, rice cultivation, Table 7 shows that rice cultivation in 1977 resulted in larger salt mass drained than applied, whereas in 1978, a smaller salt mass drained than applied, and in 1979, a large accumulation of salt in the soil occurred for the reasons explained above.

It is generally believed that the rice-transplanting period is a very critical stage in soil salt status. Insufficient water before, and after, transplanting may cause an upward movement of highly saline shallow water table instead of naturally downward flux when irrigation water is sufficient. Flushing the plots before transplanting could greatly reduce an initially high topsoil salinity (El-Gunidy and Risseeuw, 1987). However, the peak 
Table 6

Change in soil salinization $\mathrm{uS} \mathrm{cm}^{-1}$ during the rice-growing season in A. Hammad farm (west of the Nile Delta)

\begin{tabular}{|c|c|c|c|c|c|c|c|c|c|c|c|c|}
\hline \multirow{2}{*}{$\begin{array}{l}\text { Soil profile } \\
\text { Year }\end{array}$} & \multicolumn{3}{|c|}{$00-25$} & \multicolumn{3}{|c|}{$25-50$} & \multicolumn{3}{|c|}{$50-75$} & \multicolumn{3}{|c|}{$75-100$} \\
\hline & June & November & Difference & June & November & Difference & June & November & Difference & June & November & Difference \\
\hline 1977 & 6400 & 4100 & -2300 & 8100 & 5800 & -2300 & 7200 & 5500 & -1700 & 6500 & 4700 & -1800 \\
\hline 1978 & 6900 & 4300 & -2600 & 7200 & 6000 & -1200 & 6500 & 6000 & -500 & 6700 & 5400 & -1300 \\
\hline 1979 & 6600 & 7000 & 400 & 8300 & 9700 & 1400 & 5600 & 7900 & 2300 & 4200 & 5400 & 1200 \\
\hline
\end{tabular}

Source: El-Gunidy and Risseeuw (1987). 


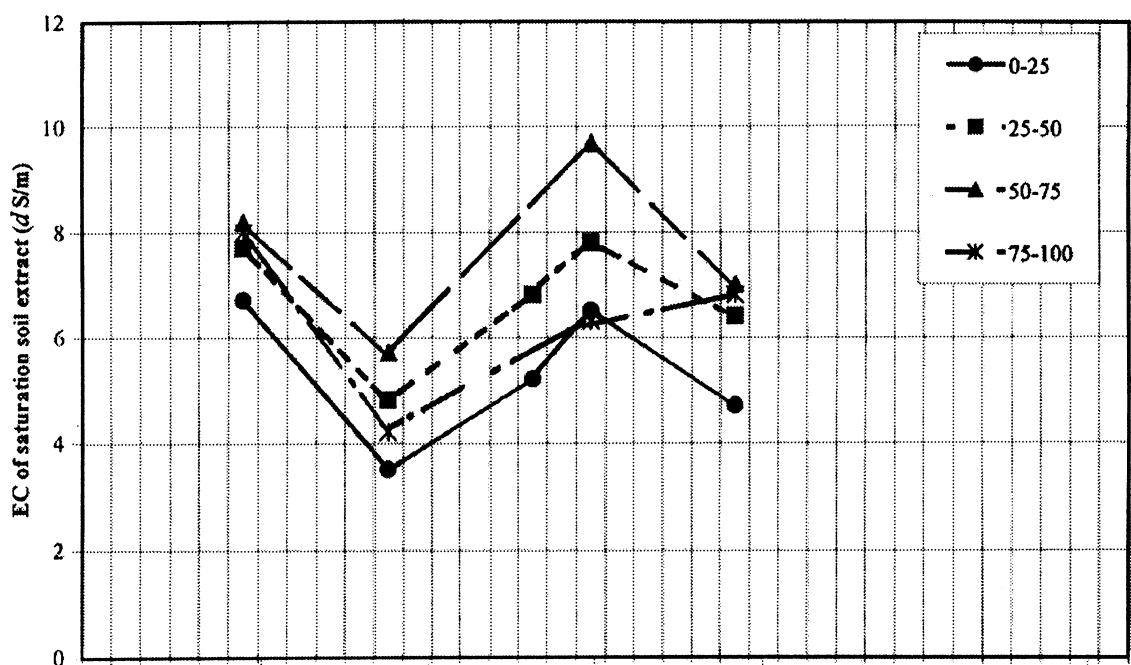

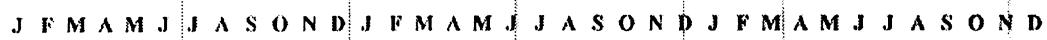

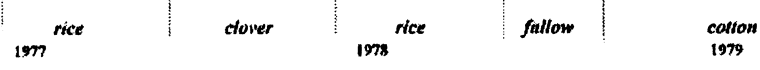

a Plot (B)

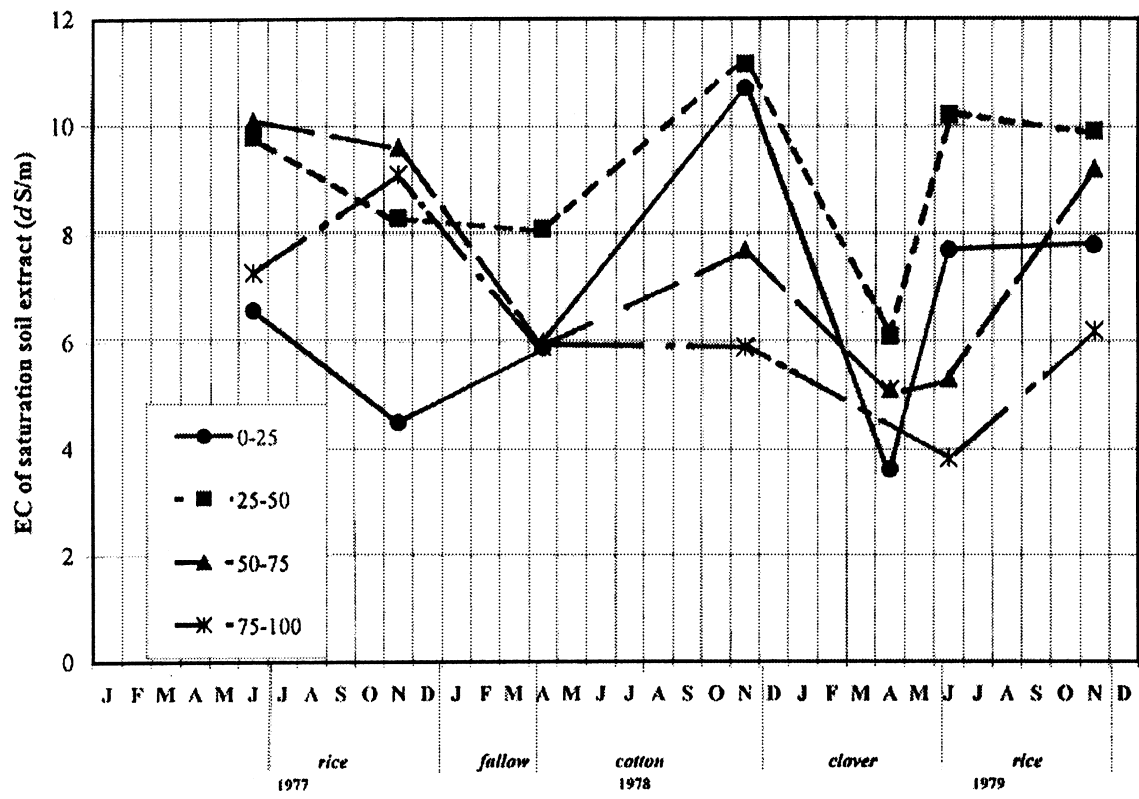

b $\quad$ Plot (C)

Fig. 8. Electric conductivity of different soil profiles corresponding to the applied cropping pattern in two plots (B and C) in A. Hammad farm in the West Delta. 
Table 7

Effect of rice cultivation in removing accumulated salts in the soil of A. Hammad farm according to the 'Salt Balance Principle' (quantities are in $\mathrm{tha}^{-1}$ )

\begin{tabular}{llll}
\hline Year & 1977 & 1978 & 1979 \\
\hline Applied salts through irrigation water & 6.1 & 6.7 & 6.9 \\
Amount of removed salts due to rice cultivation & 7.6 & 5.3 & 0.8 \\
\hline
\end{tabular}

Source: El-Gunidy and Risseeuw (1987).

demands of irrigation water occurs during this period, which in most rice areas lasts about four weeks or less.

Another important observation is that considerable resalinization of the soil took place when a non-rice crop is grown, particularly cotton. Growing clover after cotton induced soil desalinization. The soil was deeply cracked after harvesting cotton and the applied irrigation water leached salts in the topsoil layers through these cracks. However, in the case of growing clover after rice, the same effect did not occur. Clover was sown when rice was ripening on the field, while the soil was still saturated and not cracked. During May, when clover was ripening, salinization apparently took place through capillary rise of water and salts.

The research conducted by El-Gunidy and Risseeuw, although relatively early, has added considerably to the experience of growing rice in salinized soils when water is limited.

It was also reported that if only surface drainage system exists in a rice-rotated field with clover in winter and cotton in summer, the decrease in topsoil salinity is rapidly diminished. The situation is better in fields equipped with subsurface drainage system, despite the temporary blocking of the collectors for flooding of rice paddies. Water is normally in short supply in the Nile Delta during June and July, and farmers usually block the subsurface drainage system to meet rice water requirements (Ley and Tinsley, 1983; Nijland and El-Gunidy, 1984).

Water-logged fields not planted to rice require control of water table, while rice fields are kept submerged throughout most of the growing season. The subsurface drainage system installed in Egypt is based on design criteria for crops other than paddy rice. Hence, the underdrainage system during the rice-growing season results in substantial water losses and large amounts of irrigation water are applied to keep the soils submerged. When water is not available or in short supply, farmers commonly plug the outlets of drainage collectors at the manholes with whatever means at hand, e.g. straw, mud, grass and sods. This logical but undesirable practice results in a gradual siltation and reduction in conveyance capacity of the drain collectors. Furthermore, some of the upstream fields may not be equipped as yet with a subsurface drainage system and they are likely to suffer water-logging problems from downstream plugging. When the materials used to plug the collectors are removed, they cause downstream water pollution.

We can conclude that rice cultivation may be feasible in salinized soils if irrigation water is supplied in sufficient quantities and as long as it is $<1600 \mathrm{mg} \mathrm{l}^{-1}$. Table 8 gives the criteria for blending drainage waters into fresh canal waters in the Nile Delta. At a water salinity of $1600 \mathrm{mg}^{-1}$ and leaching fraction of $15 \%$, Ayers and Westcot (1976, 
Table 8

Criteria for mixing drainage and canal waters

\begin{tabular}{ll}
\hline Drain water TDS $\left(\mathrm{mg}^{-1}\right)$ & Blending ratio \\
\hline$<700$ & direct use \\
$700-1500$ & blend at $1: 1$ ratio \\
$1500-3000$ & blend at $1: 2$ ratio \\
$>3000$ & not used for irrigation \\
\hline
\end{tabular}

1985 ) estimate a $10 \%$ decrease in rice yield. With drain water re-use promulgated, it is not entirely clear in the long term what will be the salinity level of blended irrigation waters in the Delta and whether rice yields can be sustained.

\section{Discussion and recommendations}

(i) As a general conclusion, rice cultivation maybe the optimal and most effective remedial action for reclaiming salinized soils in the northern part of the Nile Delta, if improvements in the physical system and agricultural practice take place.

(ii) Egypt's policy toward agriculture and water resources management is under continuous reform in response to acute changes in the economy, not only on the national but also on international levels. Nowadays, the dilemma is how to bridge the gap between governmental policies and the actual farming practice at the field level. In other words, the coming stage necessitates the existence of harmonious and complementary performances from all the parties involved. One of the important measures of the reform policy is reducing the rice plantings to $50 \%$ of the present cropping because of current and anticipated water shortfalls. For the successful implementation of such a policy, ricegrowing areas must be consolidated and limited to the northern part of the Nile Delta, where the soil salinization problem is severest. The expected merits of this recommendation are:

(a) It will save water for expansion purposes meeting the anticipated shortage of water resources in the near future.

(b) Violations of rice cultivation decision can be easily surveyed. The present situation does not make it possible, since rice cultivation is scattered to the extent that misleads the seasonal survey by the MPWWR staff.

(c) It allows for effective design and proper installation of field facilities. For example, subsurface drainage system will be installed according to the design drainage criteria of either rice or non-rice crops.

(d) With a field level management, water losses during rice season, or water-logging in the upstream fields, can be controlled.

(e) It is also recommended to increase the local irrigation staff in the rice-growing areas to control water overuse during the period of peak water requirements.

(f) Soil fertility status can be monitored to gain more experience with respect to growing rice without rotation in salinized or potentially salinized soils. 
(g) The soil improvement efforts can be conducted in a more effective way to preserve productivity level, taking into consideration the targeted crop for cultivation. However, a fair program must be established to provide farmers in the rice-replaced areas with the appropriate financial compensations.

(iii) The success of soil improvement and structure modernization projects is highly subject to the initiation of a flexible and effective cost recovery program. Farmers' participation will be the backbone in this regard, since it will surely reduce the governmental financial burdens.

(iv) The present situation and future expectations cannot endure indulgent attitudes by the Government regarding violations. Institutionally, irrigation staff must be supported with enough power to enable them to enforce the law firmly and prevent farmers from committing violations.

(v) The agronomic policy must be reformed sensibly to enable the use of the scarce water resources efficiently, control rice plantings firmly and attain equity of farming benefits if the agricultural process is to be somehow controlled. The crop liberalization policy must be applied in its actual sense in view of the optimum utilization of water resources and the necessity for growing strategic crops. Parallel to this, the agricultural subsidy, i.e. subsidies of inputs like seeds and fertilizers, must be eliminated and market prices have to be liberalized.

(vi) The Government has to adopt a public awareness program in rural societies, in which, it explains the crucial nature of the situation and encourages farmers to co-operate willingly to overcome future challenges.

\section{Summary}

Irrigated agriculture in Egypt suffers from soil salinization in ca. 35\% of its soils, mostly located along the northern strip of the Nile Delta near the Mediterranean Sea, where rice is cultivated intensively. Recently, the Government adopted a new agrarian policy toward expanding agricultural lands in some remote areas apart from the Nile Valley and Delta. In order to save water for reclamation purposes, the Government intends to cut the rice-growing areas by almost $50 \%$ of its current plantings because rice has a comparatively high water duty. On the other hand, previous research in the Nile Delta has promoted rice cultivation as an effective remedy for salinized soils.

The efforts to control soil salinization are carried out on two tracks. The first track is the governmental efforts that includes improving the field-drainage conditions through installation of subsurface drainage systems and recovering the desirable soil properties by applying land improvement programs in which some conservation activities are carried out, such as sub-soiling, land leveling and gypsum amendments. The second track is actions taken by farmers at the field level which entirely depend on growing rice as the best tolerant crop of the existing low agrarian environment as well as yielding the highest benefit amongst all summer crops.

This paper ends with recommending rice cultivation in the heavily salinized soils in the northern part of the Nile Delta. However, it must be limited to this area where rice would 
not be rotated with other crops. Nevertheless, the agronomic system must be reformed to allow for compensating farmers financially in the rice-cut areas. The violators of this policy must be firmly deterred if the policy is to be applied successfully.

The Government has to adopt flexible cost recovery programs in generalizing the implementation of subsurface drainage systems and soil improvement projects. It is a necessary step to reduce the financial obligations of the Government on one hand, while initiate an effective contribution from farmers on the other, based upon an appropriate public-awareness plan in the rural societies. Prior to that, the agricultural process, like irrigation services, must be gradually liberalized until becoming completely free of subsidies.

\section{Acknowledgements}

The senior author acknowledges the support of the Ministry of Public Works and Water Resources of Egypt (MPWWR) for the opportunity to study abroad. The authors also acknowledge the able assistance and cooperation of MPWWR, the National Water Research Center (NWRC) and the Japan International Cooperative Agency (JICA) as well as the financial assistance of the Japanese Ministry of Education, Science and Culture (Monbusho).

\section{References}

Abdel-Aziz, Y., 1997. Land drainage for water table and salinity control, Water Resources Outlook for the 21st Century: Conflicts and Opportunities, A Special Session on Water Management under Scarcity Conditions: The Egyptian Experience, IXth World Water Congress of IWRA (International Water Resources Association), Montreal, Canada. pp. 69-79.

Aboukhaled, A., Arar, A.M., Balba, A.M., Bishay, B.G., Kadry, L.T., Rutema, P.E., Taher, A., 1975. Research on crop water use, salt affected soils and drainage in the Arab Republic of Egypt, Food and Agriculture Organization of the United Nations, Near East Regional Office, Cairo, Egypt. pp. 62-79.

Attia, A.R. Fatma, Leeuwen, H.M. van, 1994. Towards integrated water management in the fringes of the Nile Valley, VIII-IWARA World Congress on Water Resources, Egypt.

Ayers, R.S., Westcot, D.W., 1976. Water quality for agriculture, irrigation and drainage paper 29, Food and Agriculture Organization of the United Nations, Rome, Italy. pp. 79.

Ayers, R.S., Westcot, D.W., 1985. Water quality for agriculture, irrigation and drainage paper 29 Rev. 1, Food and Agriculture Organization of the United Nations, Rome, Italy.

Drainage Research Institute (DRI), 1994. Drainage water in the Nile Delta, yearbook of 1992/1993, Reuse Monitoring Programme, National Water Research Centre, Egypt.

El-Gunidy, S., Risseeuw, I.A., 1987. Research on water management of rice fields in the Nile Delta, Egypt, International Institute for Land Reclamation and Improvement/ILRI Wageningen, The Netherlands. pp. 69.

El-Gunidy, S., 1989. Quality of drainage water in the Nile Delta, In: Amer, M.H., de Ridder, N.A (Eds.), Land Drainage in Egypt, Drainage Research Institute. pp. 189-206.

El-Quosy, D., 1994. Control of water consumption of rice, VIII-IWARA World Congress on Water Resources, Egypt.

Government of the Arab Republic of Egypt (GARE), 1992. Environmental action plan, Egypt. pp. 5-29.

Kotb, Tarek H.S., Watanabe, T., Ogino, Y., Nakagiri, T., 1998. New policy for agricultural expansion in Egypt, Proceedings of the annual meeting of the Japanese Society of Irrigation, Drainage, and Reclamation Engineering, Kyoto, Japan. 
Ley, T.W., Tinsley, R.L., 1983. Irrigation and production of Rice in Abu Raya, Kafr El-Sheikh Governerate, Technical Report No. 9, Egypt Water Use and Management Project, Cairo, Egypt. pp. 64.

Master Plan for Water Resources Development and Use (MPWRDU), 1981. Consumptive use of water by major field crops in Egypt, Technical Report No. 17, Agricultural Research Center, Ministry of Agriculture and Land Reclamation and Ministry of Public Works and Water Resources. pp. 6.

Ministry of Agriculture and Land Reclamation (MALR), 1994, Agronomy Yearly Bulletin, Central Department for Agronomy, Cairo, Egypt.

Ministry of Public Works and Water Resources (MPWWR), 1997. Development of South Egypt: The New Valley Project, Egypt (in Arabic).

Nijland, H.J., El-Gunidy, S., 1984. Crop yields, water depth, and soil salinity in the Nile Delta, Egypt, Annual Report of 1983, International Institute for Land Reclamation and Improvement/ILRI, Wageningen, Netherlands. pp. 58.

Research Institute for Groundwater (RIGW), 1992. Groundwater resources and projection of groundwater development, Water Security Project, National Water Research Centre, Egypt. pp. 37.

U.S. Bureau of Reclamation, 1997. The Central Valley Project Improvement Model (CVPM), Central Valley Project Improvement Act, Draft environmental impact statement, vol. 8, Sacramento, CA, USA.

Van de Goor, G.A.W., 1967. Rice as a reclamation crop for saline soils, Annual report, International Institute for Land Reclamation and Improvement, Wageningen, Netherlands. pp. 46-55.

Water Management and Irrigation Systems Research Institute (WMISRI), personal communication, 1995. National Water Research center, Egypt. 